\title{
Distribution and ecological aspects of leptocephali collected 1979-1994 in North- and Central Atlantic. I. Congridae
}

\author{
B. Strehlow ${ }^{1 *}$, C. Antunes ${ }^{2}$, U. Niermann ${ }^{3}$ \& F.-W. Tesch ${ }^{3}$ \\ ${ }^{1}$ Universität Rostock, Abt. Stoffwechselphysiologie, Justus-von-Liebig-Weg 8, \\ D-18051 Rostock, Germany \\ ${ }^{2}$ Instituto de Ciéncias Biomédicas de Abel Salazar Universidade de Porto, \\ Lg. Prof. Abel Salazar 2, P-4000 Porto, Portugal \\ ${ }^{3}$ Biologische Anstalt Helgoland, Notkestraße 31, D-22607 Hamburg, Germany
}

\begin{abstract}
This is the first report on the leptocephalus catches made during the last 15 years in North-and Central Atlantic during the course of 19 cruises of five different ships from Germany and one from Poland. This report comprises identification, geographical occurrence and abundance and in some cases depth preference, migratory routes and spawning area of Congridae in the North Atlantic. The largest part of this collection consists of 876 Conger conger larvae. The likelihood that this species spawns in the Mediterranean is again confirmed. Decreasing density as well as increasing size from Gibraltar west- and north westward showed migration to be occurring in that direction. Age was determined by counting "daily rings" on the otoliths of up to 120 -mm long larvae. It is suggested to be more than 300 days and is calculated to be $1 \frac{1 / 4}{4}$ years for the largest larvae $(\mathrm{TL}=140-160 \mathrm{~mm})$. Some 126 specimens of three other Conger species, i.e. C. oceanicus, C. triporiceps, C. esculentus, were identified in the collection. The major part originated from the western North Atlantic. The most numerous larvae, belonging to another genus of Congridae, were Ariosoma balearicum $(n=265)$. They showed, also in consideration of other studies, quite a wide range in number of myomeres. Their systematic status is therefore uncertain, as is also the status of those known from the NW Indian Ocean and the NW Pacific. One larva, probably of Ariosoma selenops, of unusually large size $(\mathrm{TL}=467 \mathrm{~mm}$ ) and captured in the Iberian Basin is described and compared with specimens known from the literature. Two larvae of unknown identity were captured off NW Africa; they resembled $A$. balearicum but had too high a number of myomeres. The identity of most of the Gnathophis larvae caught in the East Atlantic is uncertain. Leptocephali of Paraconger notialis in the East Atlantic, up to the area north of New Guinea, exhibited a higher number of myomeres than those known from the West Atlantic. Larvae of Xenomystax congroides $(n=29)$, belonging to a population with a relatively high number of myomeres, were captured in the Sargasso Sea.
\end{abstract}

\section{INTRODUCTION}

Larvae of the Anguilliformes leptocephali collected during 19 cruises of five German and one Polish research vessels are evaluated. One part of the material was obtained during general fishery biological and oceanographical cruises in the East Atlantic. A first evaluation of the leptocephali of that material was made in the thesis of Strehlow (1992). The other part of the collection is based on cruises designated mainly for the study

\footnotetext{
- Present address of Dr. B. Strehlow: Sonnenblumenweg 13, D-18119 Rostock
} 
of the oceanic life of the North Atlantic Anguilla species (e.g. Tesch, 1982; Tesch \& Wegner, 1990) and, in addition, for monitoring the density of Anguilla larvae stocks arriving annually at the European continental slope (e. g. Tesch, 1980; Tesch \& Niermann, 1992).

This comparatively large amount of material contributes substantially to our knowledge on the occurrence, migration and spawning areas of several anguilliform species in the North Atlantic. It comprises more than 30 species and a total number of about 4000 specimens. A systematic presentation of this material by taxonomic order alone, to supplement the ecological view, is beyond the scope of this paper. The taxonomic information is therefore combined with geographical and regional aspects. The first paper includes species which occur and spawn mainly in the East Atlantic, although West Atlantic occurrence is also described. Congridae, like Conger conger, Ariosoma and Gnathophis species are included in this first presentation. Conger conger is of special interest because its collection is the most substantial of this section and comprises catches obtained from 1979 to 1994 . Species of other families are considered in later papers.

\section{MATERIAL AND METHODS}

The study material of eel larvae was collected during 20 expeditions of six research vessels between 1979 and 1994. The cruises were conducted by the Biologische Anstalt Helgoland (R. V. "F. Heincke", R. V. "A. Dohrn"), by the former Institut für Hochseefischerei, Rostock in cooperation with the Marine Institut, Gdynia (R. V. "A. v. Humboldt". R. V. "Prof. Siedlecki") and by the Institut für Meereskunde, Kiel (R. V. "Poseidon") (Table 1). Because the program of some cruises was not especially designed for catching eels and eel larvae and due to the different catching methods and gear, calculations and comparison of mean abundances were not possible. After capture, the leptocephali were preserved in seawater formalin $(4 \%)$ or ethanol $(70 \%)$. Measurements were made to nearest $0.1 \mathrm{~mm}$, counts and identification under magnifications of 125 and 500, partly on board and partly in the laboratory. A screening of all available samples was necessary. As some specimens were loaned or in bad condition due to preservation for a long period, the identity of some species could not be confirmed. Specimens of Bathycongrus (formerly Rhechias) and Hildebrandia especially could only be identified to genus level.

The following abbreviations are used: $\mathrm{n}$ - number of specimens, $\varnothing$ - mean value, s.d. - standard deviation, TL - total length, preAL - preanal length, preDL - predorsal length, LO - length to the opisthonephric blood vessel, LH - length of the head, D greatest depth of the body, TNM - total number of myomeres, MP - number of myomeres to the pronephric blood vessel, $\mathrm{MO}$ - number of myomeres to the opisthonephric blood vessel, MA - number of myomeres to the origin of the anal fin, $\mathrm{MD}$ - number of myomeres to the origin of the dorsal fin, FC - number of fin rays in the caudal fin.

\section{RESULTS AND DISCUSSION}

\section{Conger conger}

\section{Morphometry and meristics}

The Conger larvae were differentiated mainly by counting myomeres. The 876 Conger larvae, which were collected in the NE-Atlantic and Mediterranean during 
Table 1. Sources of examined leptocephali material from the North Atlantic

\begin{tabular}{|c|c|c|c|c|c|}
\hline $\begin{array}{l}\text { Exp. } \\
\text { Nr. }\end{array}$ & Date & Research vessel & Catching area & Gill & $\begin{array}{l}\text { Mesh size } \\
(\mu \mathrm{m})\end{array}$ \\
\hline 1. & 12. 02. -09.05 .1979 & $\begin{array}{l}\text { "F. Heincke" } \\
\text { "A. Dohrn" }\end{array}$ & $\begin{array}{l}\text { Bay of Biscay, } \\
\text { Sargasso Sea }\end{array}$ & $\begin{array}{l}\text { IKMT } \\
\text { MOC }\end{array}$ & $\begin{array}{l}500,850 \\
335\end{array}$ \\
\hline 2. & 14. 08.-01. 09. 1980 & "W. Herwig" & $\begin{array}{l}\text { North Atlantic near the } \\
\text { northern European coast }\end{array}$ & $?$ & $?$ \\
\hline 3. & 17. 08.-23.08. 1980 & "F. Heincke" & $\begin{array}{l}\text { North Atlantic west of } \\
\text { Ireland }\end{array}$ & IKMT & 1000 \\
\hline 4. & 18. $02 .-23.04 .1981$ & "F. Heincke" & $\begin{array}{l}\text { Bay of Biscay, } \\
\text { western North Atlantic }\end{array}$ & IKMT & $\begin{array}{l}500,850 \\
1800\end{array}$ \\
\hline 5. & 28. 10.-21. 11. 1982 & "F. Heincke" & $\begin{array}{l}\text { Bay of Biscay, } \\
\text { Gibraltar }\end{array}$ & IKMT & 1800 \\
\hline 6. & 16. 03.-10.04. 1983 & "A. v. Humboldt" & $\begin{array}{l}\text { Central North Atlantic } \\
\text { near the coast of NW- } \\
\text { Africa }\end{array}$ & $\mathrm{PT}$ & 4000 \\
\hline 7. & 10. 11.-11.12.1983 & "F. Heincke" & $\begin{array}{l}\text { Bay of Biscay, } \\
\text { Mediterranean }\end{array}$ & IKMT & 1800 \\
\hline 8. & 16. 07.-12. 10. 1984 & "Prof. Siedlecki" & Iberian Basin & $\mathrm{PT}$ & 4500 \\
\hline 9. & 15. 11.-13. 12. 1984 & "F. Heincke" & $\begin{array}{l}\text { Bay of Biscay, } \\
\text { Gibraltar }\end{array}$ & IKMT & 1800 \\
\hline 10. & 31. 03.-18.04. 1985 & "Prof. Siedlecki" & Central North Atlantic & $\mathrm{PT}$ & 6000 \\
\hline 11. & 11. 11.-14.11. 1985 & "F. Heincke" & Bay of Biscay & IKMT & 1800 \\
\hline 12. & 31. 10.-08. 11. 1986 & "F. Heincke" & $\begin{array}{l}\text { Bay of Biscay, } \\
\text { Coast of Portugal }\end{array}$ & IKMT & 1800 \\
\hline 13. & $06.11 .-15.11 .1987$ & "F. Heincke" & $\begin{array}{l}\text { Bay of Biscay, } \\
\text { Coast of Portugal }\end{array}$ & IKMT & 1800 \\
\hline 14. & 12. 11.-20.11. 1988 & "F. Heincke" & $\begin{array}{l}\text { Bay of Biscay, } \\
\text { Coast of Portugal }\end{array}$ & IKMT & 1800 \\
\hline 15. & 25. 05.-01.06. 1989 & "F. Heincke" & $\begin{array}{l}\text { Bay of Biscay, } \\
\text { Coast of Portugal }\end{array}$ & IKMT & 1800 \\
\hline 16. & 13. 07.-07. 10. 1989 & "A. v. Humboldt" & $\begin{array}{l}\text { Central North Atlantic } \\
\text { near the coast of NW- } \\
\text { Africa }\end{array}$ & Bongo & 315,400 \\
\hline 17. & 23. 10.-28. 10. 1991 & "F. Heincke" & $\begin{array}{l}\text { Bay of Biscay, } \\
\text { Coast of Portugal }\end{array}$ & IKMT & $1800 ?$ \\
\hline 18. & 15. 02. -05. 04. 1993 & "Poseidon" & $\begin{array}{l}\text { Bay of Biscay, } \\
\text { Sargasso Sea }\end{array}$ & $\begin{array}{l}\text { IKMT } \\
\text { Bongo } \\
\text { MOC }\end{array}$ & $\begin{array}{l}300,4000 \\
500 \\
50\end{array}$ \\
\hline 19. & 30. 05.-22. 06. 1994 & "Poseidon" & Coast of Portugal & $\begin{array}{l}\text { IKMT } \\
\text { Bongo } \\
\text { MOC } \\
\text { PT }\end{array}$ & $\begin{array}{l}4000 \\
335,500 \\
335 \\
10.000\end{array}$ \\
\hline $\begin{array}{l}\text { IKMT } \\
\text { MOC } \\
\text { PT }\end{array}$ & \multicolumn{5}{|c|}{$\begin{array}{l}\text { - Isaacs-Kidd Midwater Trawl } \\
\text { - (MOCNESS) Multiple Opening Closing Net Environmental Sensing System } \\
\text { - Pelagic Fishery Trawl }\end{array}$} \\
\hline
\end{tabular}


1979-1994, were all Conger conger (number of expeditions: 1, 2, 3, 4, 5, 7, 8, 9, 10, 13, 14, $17,18,19$ - Table 1). The total number of myomeres of $C$. conger leptocephali varies between 154 and 162 (Table 2). Four other Conger species which, up to now, are known from the NW-Atlantic were also present in the collection, i.e. C. oceanicus with 140-148 myomeres, C. esculentus with 133-135 myomeres, C. triporiceps with 150-158 myomeres and leptocephali of Congridae genus A species A with 130 myomeres (Smith, 1989). The larvae of $C$. conger and C. triporiceps are very similar in number of myomeres. Until now they were distinguished only by their catch position either in the East- or in the West-Atlantic. In contrast to the larvae, the adults of both species differ distinctly with regard to the number of their pores and in their dentition. C. conger occurs only in the East-Atlantic, Mediterranean and Black Sea and in depths up to $500 \mathrm{~m}$. C. triporiceps occurs only in the tropical West-Atlantic, frequently near coral reefs and in surface waters (Smith, 1981, 1989; Böhlke \& Chaplin, 1968). The number of myomeres of C. conger leptocephali, as well as other characters such as body shape, pigmentation and dental patterns agree well with the corresponding data found by other authors (Table 3).

Table 2. Comparison of morphometric and meristic characters of Conger conger larvae in the NE-Atlantic and Mediterranean

\begin{tabular}{|c|c|c|c|c|}
\hline Parameter & Present studies & $\begin{array}{c}\text { D'Ancona } \\
\text { (1931) }\end{array}$ & $\begin{array}{c}\text { Schmidt } \\
(1931)\end{array}$ & $\begin{array}{l}\text { Castle } \\
(1970)\end{array}$ \\
\hline $\mathrm{n}$ & $355^{*}$ & $? \cdot \cdots$ & 201 & 2 \\
\hline \multirow[t]{2}{*}{$\mathrm{TL}(\mathrm{mm})$} & $32-165$ & $8-150$ & - & $91.5-127$ \\
\hline & \multicolumn{4}{|c|}{ Proportions ( $\%$ of $T L)$} \\
\hline preAL & $73.4-88.8$ & $84-88$ & - & - \\
\hline preDL & $55.1-78.5$ & - & - & - \\
\hline LBO & $45.3-51.0$ & - & - & - \\
\hline LH & $4.0-7.1$ & - & - & - \\
\hline \multirow[t]{2}{*}{$\mathrm{D}$} & $7.3-10.8$ & $7-8$ & - & - \\
\hline & \multicolumn{4}{|c|}{ Meristic values } \\
\hline TNM & $154-162$ & $148-155$ & $154-163$ & $154-159$ \\
\hline MP & $14-21$ & - & - & - \\
\hline $\mathrm{MO}$ & $56-61$ & - & - & $58-59$ \\
\hline MA & $119-128$ & $93 * *$ & - & $120-123$ \\
\hline $\mathrm{MD}$ & $72-91$ & - & - & - \\
\hline FC & $9-10$ & - & - & $9-10$ \\
\hline \multicolumn{5}{|c|}{$\begin{array}{l}* \mathrm{n}=355 \text { for TNM-values, for other parameters } \mathrm{n}=65-70 \\
\cdots \text { number of specimens uncertain } \\
\cdots \text { one specimen of } 8 \mathrm{~mm}\end{array}$} \\
\hline
\end{tabular}

There is little information about the development of morphometric body proportions of $C$. conger leptocephali, but we were able to analyse our material of large premetamorphic larvae for this character. The anus does not begin to move to a distinctly more anterior position until specimens have attained a total length of $150 \mathrm{~mm}$. Preanal, predorsal and head length, as well as body height increases in relation to the total length. The total length and the number of myomeres are not correlated (Fig. 1). Of importance, 
Table 3. Frequency distribution of different numbers of myomeres of Conger Conger larvae caught in the NE-Atlantic during 1979-1994

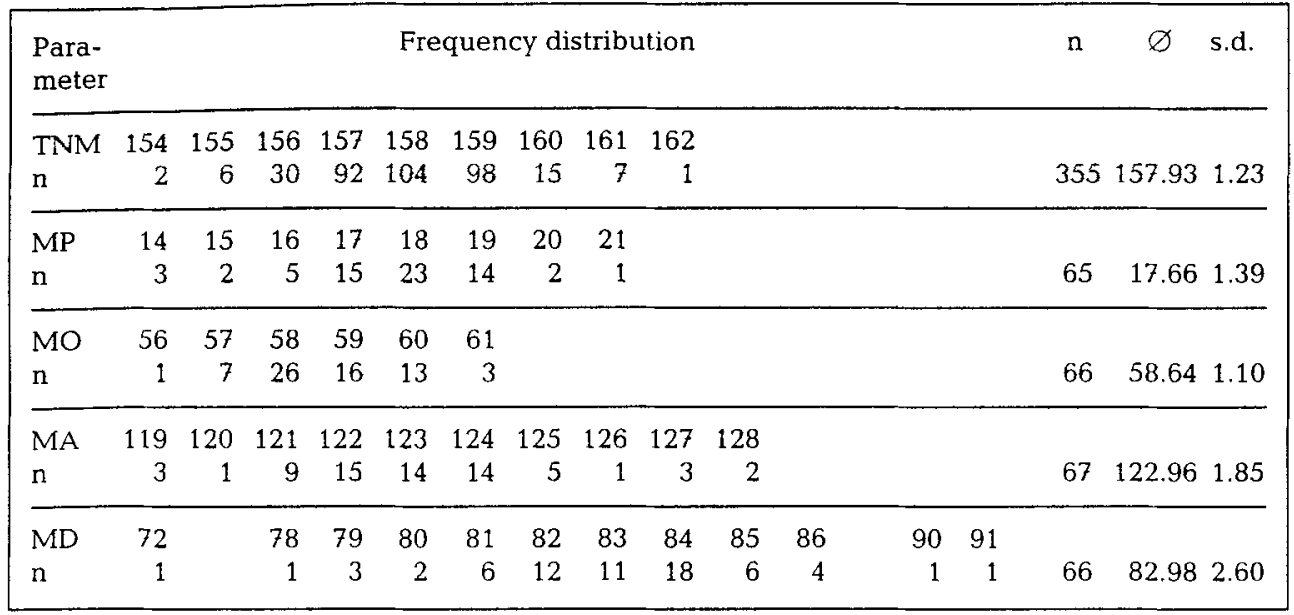

and very similar to Conger, is the genus Gnathophis; but species of this genus have a higher count of myomeres, a shorter and rounder snout, a shorter preanal length and sparser postanal pigmentation.

\section{Horizontal and vertical distribution}

The total number of $C$. conger leptocephali and their average total length in different subareas of the NE-Atlantic are presented in Figure 2. SW of Gibraltar only very few larvae were caught; in the neighbourhood NW of Gibraltar far more larvae were collected

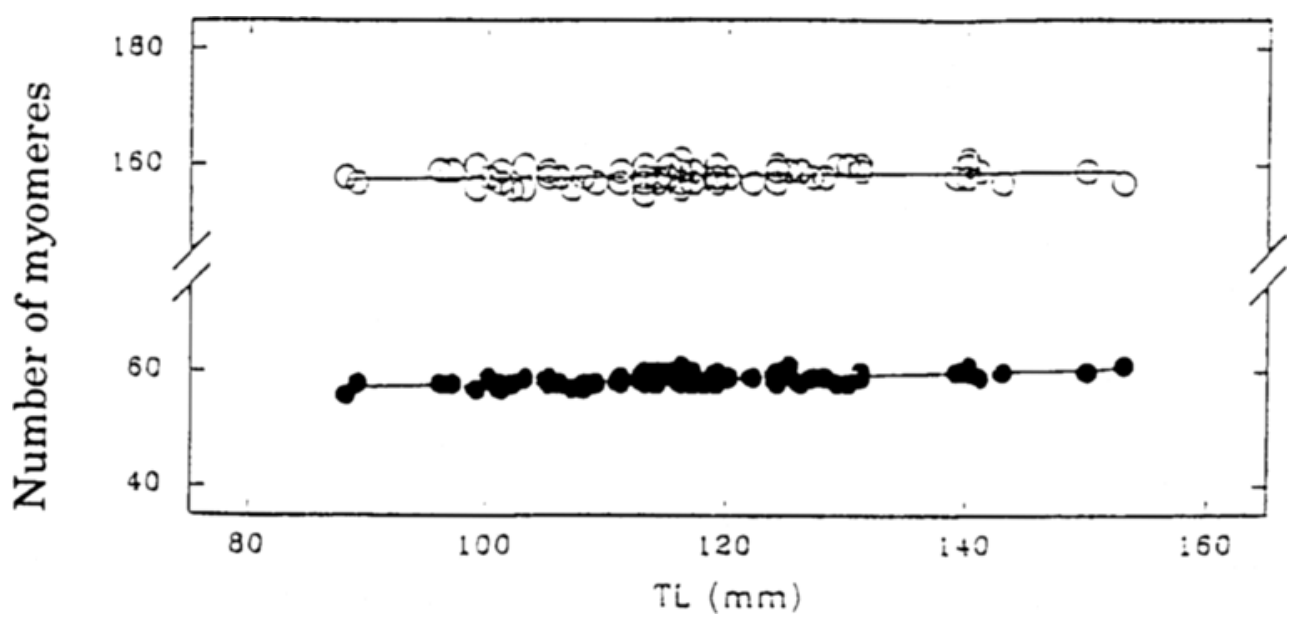

Fig. 1. Regression lines of the total number of myomeres $(O)$ and the number of myomeres to the opisthonephric blood vessel (O) according to the total length for $C$. conger larvae;

$$
\begin{aligned}
\mathrm{TNM} & =0.023 \mathrm{TL}+155.51 \\
\mathrm{MO} & =0.051 \mathrm{TL}+52.77
\end{aligned}
$$




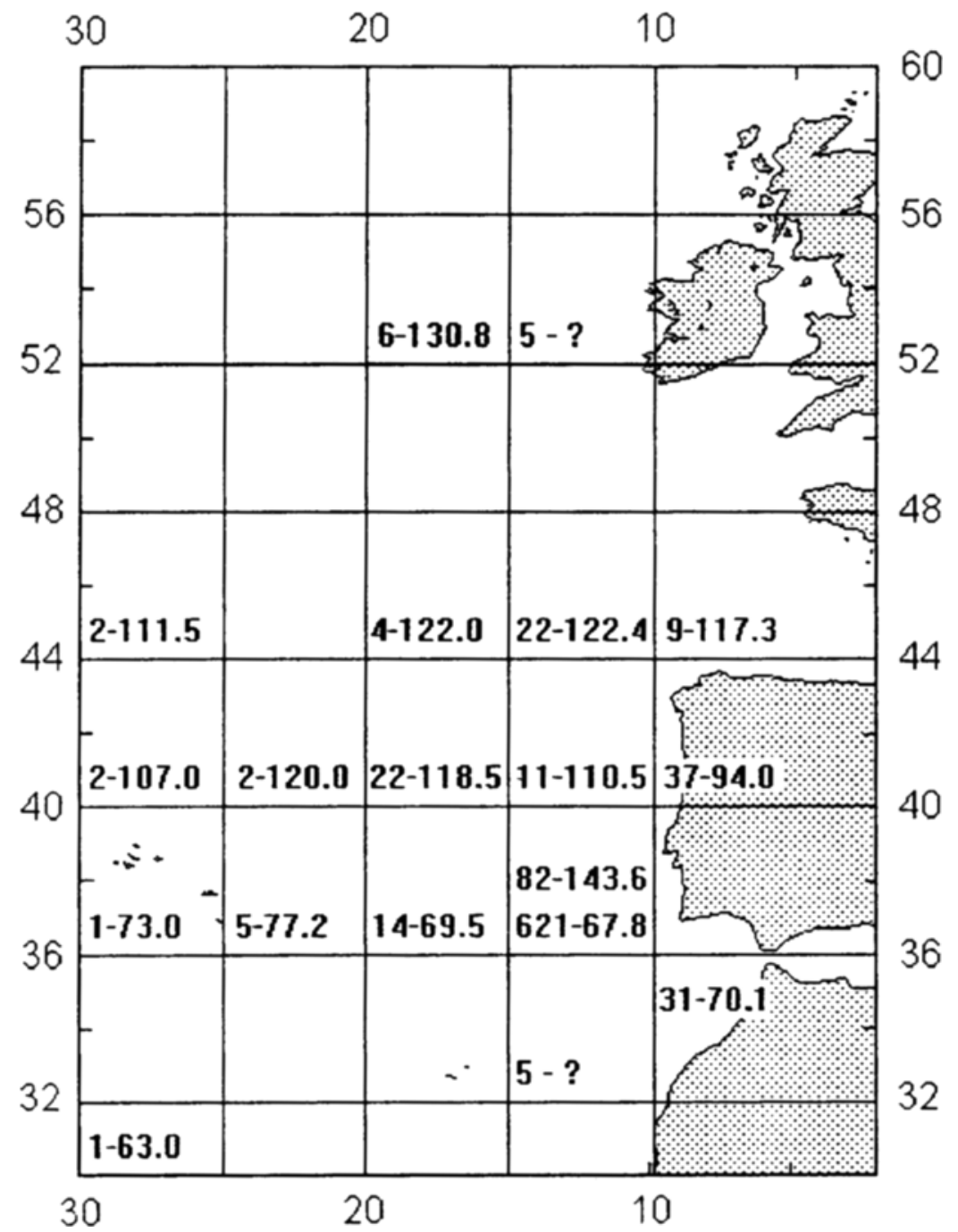

Fig. 2. Horizontal distribution of the mean lengths of $C$. conger larvae from different areas of the NEAtlantic. First values: number of individuals; second values: mean length ( $\mathrm{mm}$ ) of larvae caught in the subarea; upper values: data of summer cruise of "Poseidon", 1994

by the same catching methods. A decrease of abundance to the west is especially shown by one cruise in 1982 with successive samples from east to west (Fig. 3). The increase of mean total length in the subareas from south to north as well as a decreasing frequency in the directions north and west suggests a migration to the NW which extends comparatively far to the East and Central Atlantic. This cruise and the sampling technique were especially designed to catch Anguilla larvae. That the technique was also effective for leptocephali of $C$. conger was shown by MOCNESS samples studying depth occurrence of leptocephali in the area west of Gibraltar. The other anguilliform larvae, mainly re- 


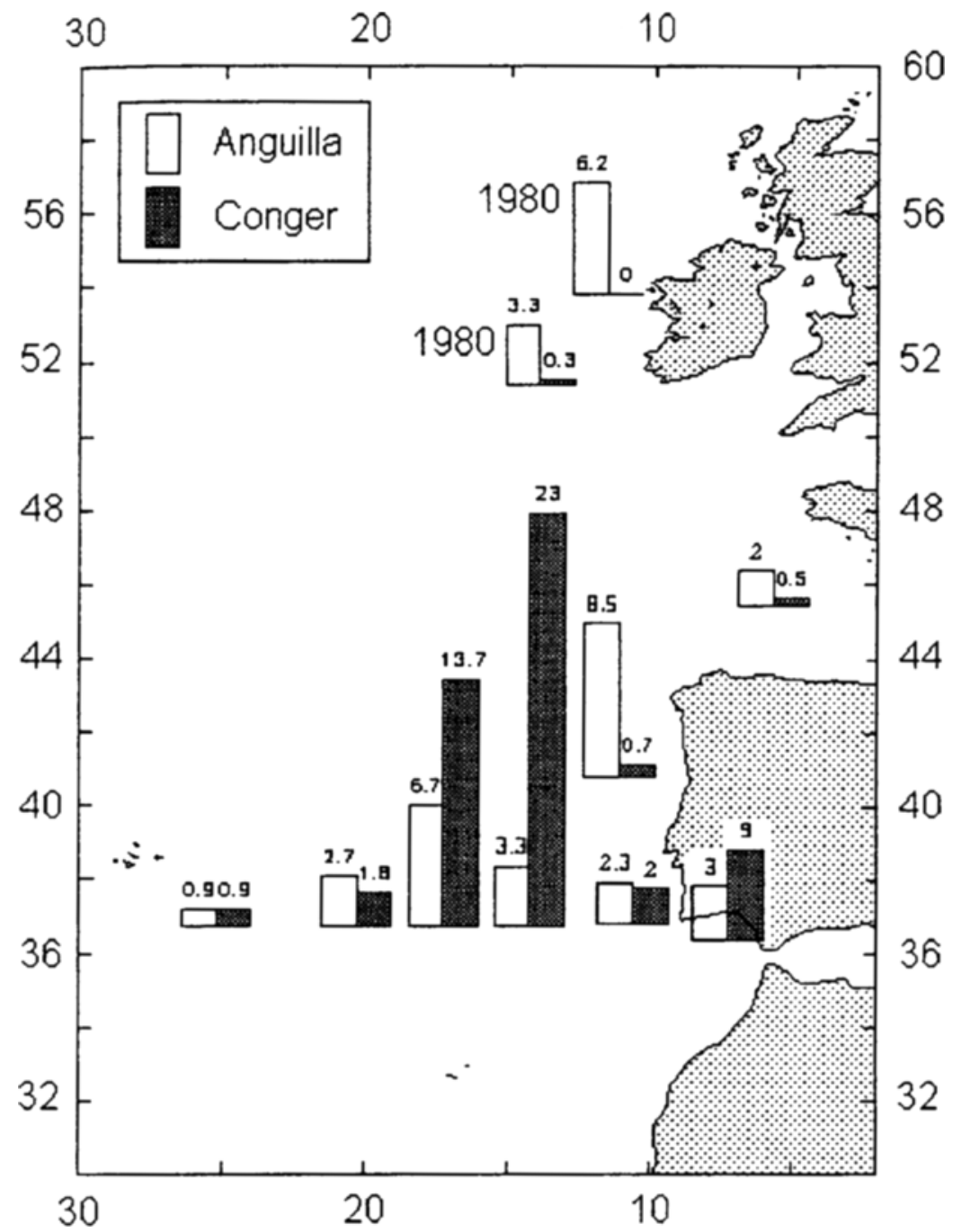

Fig. 3. Abundances of $C$. conger and $A$. anguilla larvae caught during the cruises of R.V. "F. Heincke" 1980 and 1982 (values - larvae per hour)

presented by $C$. conger, occurred during the night presumably between 0 and $200 \mathrm{~m}$, whilst $A$. anguilla larvae preferred a depth of $0-150 \mathrm{~m}$ (Tesch et al., 1986).

The described tendency of a NW increase in the length of $C$. conger leptocephali was found exclusively in catches from August to May. In contrast, one summer cruise ("Poseidon" 1994), end of May to June, provided not too far west of Gibralta, much larger sizes of $C$. conger larvae than did the winter catches (Fig. 2). These specimens were perhaps one year old, and were larvae that had not moved too far away from Gibraltar to the NW, or could have been returning from the NW. 
That the spawning place is not somewhere in the East Atlantic is demonstrated by the fact that our samples did not contain any larva below $30 \mathrm{~mm} \mathrm{TL}$. The only season when we captured the smallest larvae of $35-75 \mathrm{~mm}$ TL was early winter (Nov./Dec. Table 4). We agree therefore with Schmidt (1913) that spawning in the Mediterranean takes place in August (July to September). The assumption of Schmidt (1931) that Conger spawns in the Mediterranean is based on his catches of small, 9- to 20-mm long, larvae in that area. Schmidt's assumption that Atlantic C. conger could spawn, like A. anguilla, in the Western Sargasso Sea is based on the fact that he captured small Conger larvae in the Sargasso Sea. But this conclusion is now no longer valid. These small Conger larvae from the Sargasso Sea with a relatively high number of myomeres in relation to other Conger species of the western Atlantic have to belong to $C$. triporiceps (McCleave \& Miller, 1994). The two species are separated by a line which runs from the Canary Isles in a NW direction and to the area west of the Azores. C. conger larvae occur only in the East- and Central Atlantic.

Table 4. The total length of Conger conger larvae caught in the NE-Atlantic in relation to time of sampling

\begin{tabular}{|lcccc|}
\hline Parameter & Nov.Jan. & Febr-April & May-July & Aug.-Sept. \\
\hline Minimum TL (mm) & 32 & 79 & 93 & 81 \\
Maximum TL (mm) & 145 & 143 & 165 & 150 \\
Mean TL (mm) & 67.61 & 106.39 & 135.16 & 106.44 \\
s.d. & 16.91 & 15.74 & 18.09 & 22.68 \\
n & 673 & 38 & 116 & 48 \\
\hline
\end{tabular}

On the basis of Figures 2 and 4 we further hypothesise that, from November on, there is sufficient time for the more than $30-\mathrm{mm}$ long young larvae to leave the Mediterranean in the direction of the Atlantic and to attain the small size that we have found repeatedly south of Portugal/Spain. They then grow, until the early summer, to a TL of $130-150 \mathrm{~mm}$ (up to $165 \mathrm{~mm}$ ). From their wide distribution area in the Eastern Atlantic some return for metamorphosis to the coastal waters of the continental slope and to the Mediterranean. This is suggested by the mixed occurrence of small and large larvae observed from November to January west of Gibraltar (see also Schmidt, 1931). The length interval of caught larvae and the standard deviation is here double that of other seasons and areas (Table 4). This may show that here emigrating and immigrating larvae are crossing their migratory paths. Nothing is known on location and time of metamorphosis.

\section{Age determination by daily rings}

The possible ages of 21 C. conger larvae caught in October 1991 by R. V. "F. Heincke" were determined by counting the so-called daily rings in the otoliths. The method was the same as that used for larvae and glass eels of A. anguilla (Antunes, 1994; Antunes \& Tesch, 1997). Considering the area of capture, the investigations showed an increase of size and age from south to north. Larvae of about $90 \mathrm{~mm}$ are 8 months old and a larva with a total length of $116 \mathrm{~mm}$ is about 10 months old (Table 5). 


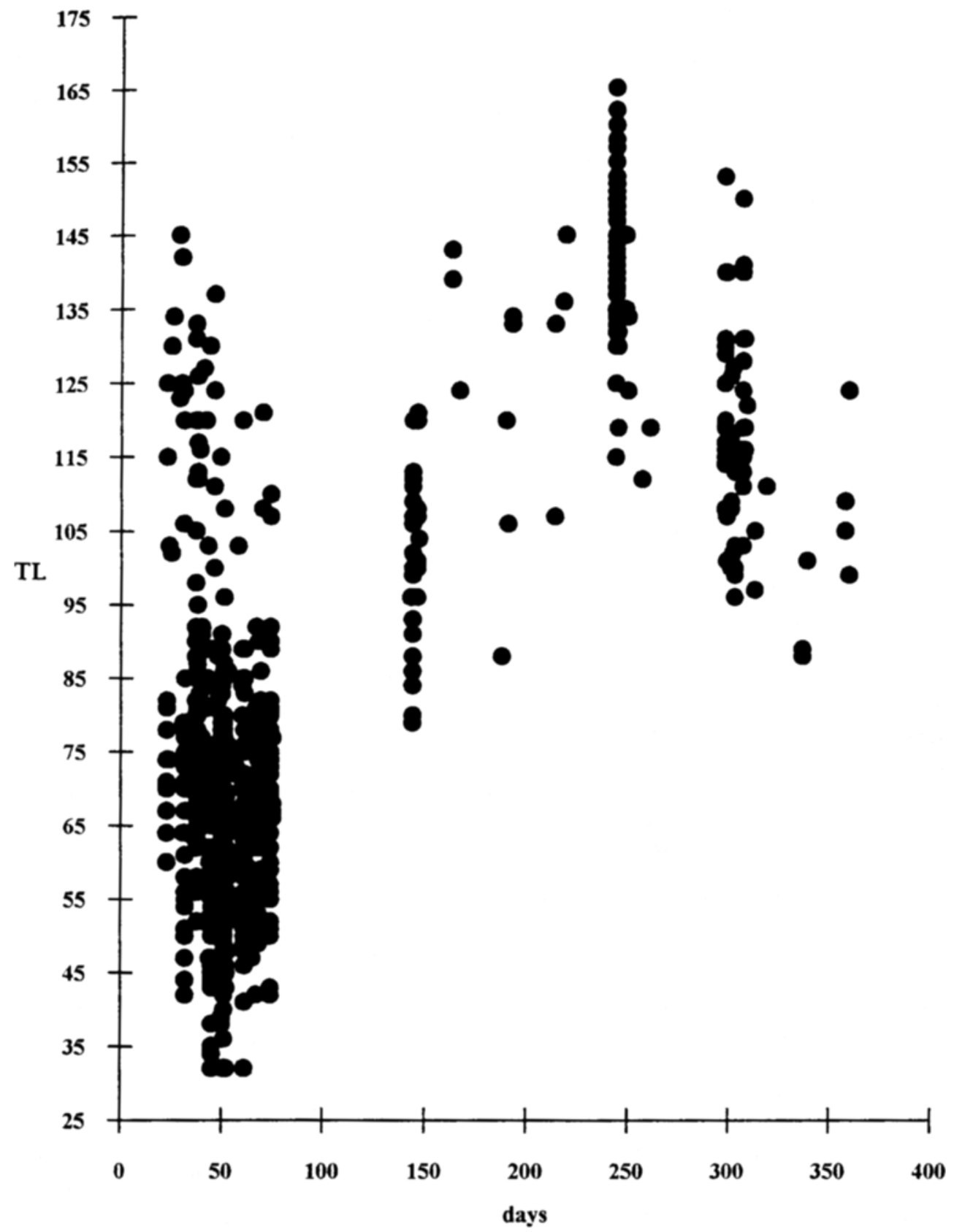

Fig. 4. Total length $(\mathrm{mm})$ of $C$. conger larvae in relation to day of the year when collected (first day on the left is November 1st) 
Table 5. Age determination by daily rings and diameter of otoliths of Conger conger larvae caught in the East-Atlantic in spring 1989

\begin{tabular}{|c|c|c|c|c|c|}
\hline Area & $\mathrm{n}$ & $\begin{array}{l}\varnothing \mathrm{TL} \\
(\mathrm{mm})\end{array}$ & $\begin{array}{c}\varnothing \text { radius of } \\
\text { otoliths }(\mu \mathrm{m})\end{array}$ & $\begin{array}{c}\varnothing \text { diameter of } \\
\text { otoliths }(\mu \mathrm{m})\end{array}$ & $\begin{array}{c}\varnothing \text { number of } \\
\text { daily rings }\end{array}$ \\
\hline Bay of Biscay & 7 & 116 & $160($ s.d. $=28)$ & 243 (s.d. $=47)$ & $306($ s.d. $=44)$ \\
\hline North coast of Portugal & 11 & 108 & $154(\mathrm{~s} . \mathrm{d} .=26)$ & 241 (s.d. $=51)$ & $292($ s.d. $=43)$ \\
\hline Northern Iberian Basin & 3 & 91 & 130 & 190 & 234 \\
\hline
\end{tabular}

Based on the age determination according to the "daily rings" of the otoliths, an age of 8 to 10 months is likely. Spawning therefore must have taken place between July and September i.e. in agreement with the assumption of Schmidt (1913) obtained from his catch of the smallest larvae in the Mediterranean. Thus, the very large larvae of 140 to $160 \mathrm{~mm}$ caught during the "Poseidon" cruise of the early summer 1994 could, by extrapolation, be nearly $1 \frac{1}{4}$ years old (400-425 rings). The calculated age is in accordance with the hypothetical age of the larval phase of $C$. conger described above.

\section{Conger oceanicus, Conger esculentus, Conger triporiceps}

The catch of 126 larvae enabled three other species of the genus Conger, apart from the leptocephali of $C$. conger, to be investigated. They originated from the expeditions Nr. 1, 4 and 18 (Table 1). Most were captured in the western region of the North-Atlantic and in none of the samples were two different Conger species caught. The results are shown in Table 6 . We only considered those individuals for which exact catch and identification data or the preserved samples were provided. Some specimens were measured fresh on board. The others were measured after fixation for several years. After several years in formalin the total length had shrunk by up to $10 \%$. Therefore body length is not comparable and an evaluation of horizontal size distribution is not possible.

Table 6. Conger larvae caught in the western North Atlantic during February-April 1979, 1981 and 1993

\begin{tabular}{|lccccc|}
\hline Species & $\mathrm{n}$ & TL $(\mathrm{mm})$ & TNM & $\varnothing$ TNM & s.d. \\
\hline C. oceanicus & 44 & $19-104$ & $139-151$ & 144.7 & 2.30 \\
C. triporiceps & 41 & $24-129$ & $150-160$ & 155.8 & 1.83 \\
C. esculentus & 2 & $36-100$ & $133-135$ & 134.0 & - \\
Four larvae were metamorphosing & & & & \\
\hline
\end{tabular}

The total number of larvae of $C$. triporiceps caught was 80 , but their condition was too poor for examination. Four larvae with TL from 95 to $129 \mathrm{~mm}$ were metamorphosing (catching dates: $15.4 .1979 ; 35^{\circ} 51^{\prime} \mathrm{N}, 6^{\circ} 58^{\prime} \mathrm{W}$ ). Concerning $C$. esculentus leptocephali, besides uncertain identity, the condition of pigmentation was such as to preclude identification of the stage of development. This question was also left open by Smith (1989). 


\section{Ariosoma balearicum}

Leptocephali of Ariosoma are easy to identify by their slender shape, their long and simple intestine, their very short dorsal fin and their characteristic rows of short pigment series along the myosepta. The larvae of Ariosoma balearicum can be differentiated distinctly from the other species of this genus by counting the TNM and by the single pigment series below the midlateral level. $A$. balearicum is one of the most frequently caught larval species in tropical and subtropical latitudes of the Atlantic, and several other descriptions are therefore available (Table 7).

Table 7. Comparison of morphometric and meristic characters of Ariosoma balearicum larvae in the North Atlantic

\begin{tabular}{|c|c|c|c|c|}
\hline Parameter & Present studies & $\begin{array}{c}\text { Smith } \\
(1971,1989)\end{array}$ & $\begin{array}{c}\text { Blache } \\
(1977)\end{array}$ & $\begin{array}{l}\text { Castle } \\
(1966)\end{array}$ \\
\hline $\mathrm{n}$ & 265 & 3131 & $175^{*}$ & $155^{*}$ \\
\hline \multirow[t]{2}{*}{$\mathrm{TL}(\mathrm{mm})$} & $7-173$ & $4-205$ & $8-216$ & $100-209$ \\
\hline & \multicolumn{4}{|c|}{ Proportions ( $\%$ of $T L)$} \\
\hline preAL & $87.4-97.1$ & $87.0-98.0$ & $78.7-97.9$ & - \\
\hline preDL & $92.6-98.2$ & - & $92.7-96.8$ & - \\
\hline $\mathrm{LH}$ & $2.8-8.6$ & $3.0-12.0$ & - & - \\
\hline \multirow[t]{2}{*}{$\mathrm{D}$} & $6.8-17.6$ & $8.0-17.0$ & - & - \\
\hline & \multicolumn{4}{|c|}{ Meristic values } \\
\hline TNM & $124-136$ & $121-136$ & $126-138$ & $123-131$ \\
\hline MP & $18-26$ & - & $14-16$ & $12-16$ \\
\hline MO & $56-64$ & $62-72$ & $63-71$ & $65-69$ \\
\hline MA & $114-124$ & $90-126$ & - & $52-121$ \\
\hline MD & $115-128$ & - & - & - \\
\hline $\mathrm{FC}$ & $5-7$ & - & $6-8$ & $6-8$ \\
\hline
\end{tabular}

Larvae caught in the West- as well as in the East-Atlantic display a wide range of TNM. The smallest and greatest known numbers (121 and 138) differ by 18 myomeres. In larvae of other eel species which in addition agree in all essential features and which also can only be identified by myomere count, this difference is less. In A. anguilla and in $A$. rostrata leptocephali a comparatively small difference of 7 myomeres is sufficient for differentiation; and in other eel species even less (Castle, pers.comm.; Tesch, 1983).

However, distinct geographical differences of the TNM of A. balearicum larvae suggest the existence of several groups characterized by different myomere counts. Smith (1989) describes three populations for adult A. balearicum of the Western Atlantic, one northern and one southern population with a high number of vertebrae and one geographical intermediate population with a low number of vertebrae. Clearly, for all adults of the Western Atlantic there is a length frequency distribution with two peaks (125 and 131). These two peaks are also observable in the number of myomeres of the larvae (126 and 132). However, it was not possible to characterize the three different adult populations by larval myomere counts. 
Table 8. Total numbers of myomeres of Ariosoma balearicum larvae caught in Mediterranean, coastal and oceanic regions of the North Atlantic

\begin{tabular}{|rllll|}
\hline $\mathrm{n}$ & $\varnothing \mathrm{TNM}$ & s.d. & Area & Author \\
\hline 20 & 131.95 & 2.28 & Mediterranean & Grassi (1913) \\
12 & 126.58 & 1.16 & Iberian Basin & Strehlow (1992) \\
7 & 128.14 & 3.24 & NW-Africa & Strehlow (1992) \\
23 & 129.39 & 2.52 & Cape Verde Islands & Blache (1977) \\
115 & 127.70 & 1.99 & Cape Verde Islands, NW-Africa & Castle (1966) \\
\hline 157 & 127.88 & 2.19 & Summary of coastal regions & \\
\hline 107 & 130.44 & 2.15 & Gulf of Guinea & Blache (1977) \\
81 & 132.97 & 1.71 & Central East-Atlantic & Lea (1913) \\
30 & 133.20 & 1.69 & Central East-Atlantic & Blache (1977) \\
\hline 218 & 131.76 & 2.33 & Summary of oceanic regions & \\
\hline
\end{tabular}

The larvae of $A$. balearicum in our study and in other investigations have on average 3-5 myomeres more in the open ocean and in the Mediterranean than in coastal areas (Table 8). Schmidt (1912) mentioned earlier that the larvae of A. balearicum from the Mediterranean exhibited 2 to 3 myomeres less than the larvae of the Central Atlantic. Castle (1966) supports this hypothesis by comparing the TNM of the specimens captured in 1964 by "W. Herwig" and those of the "Sars"-Expedition in 1910. These differences in the numbers of myomeres are difficult to explain. The two possible spawning areas of A. balearicum in the East-Atlantic, on the basis of the occurrence of very small larvae, are presumably in the Mediterranean (Grassi, 1913) and in the Gulf of Guinea (Blache, 1977). In these two areas leptocephali with high numbers of myomeres were caught. Therefore the hypothesis of different populations of $A$. balearicum with different spawning areas characterized by different myomere numbers is not supported by our larval data. The frequency distribution of the TNM data of all pooled data of $A$. balearicum leptocephali of the East Atlantic and the Mediterranean resembled a plot with two peaks (Fig. 5).

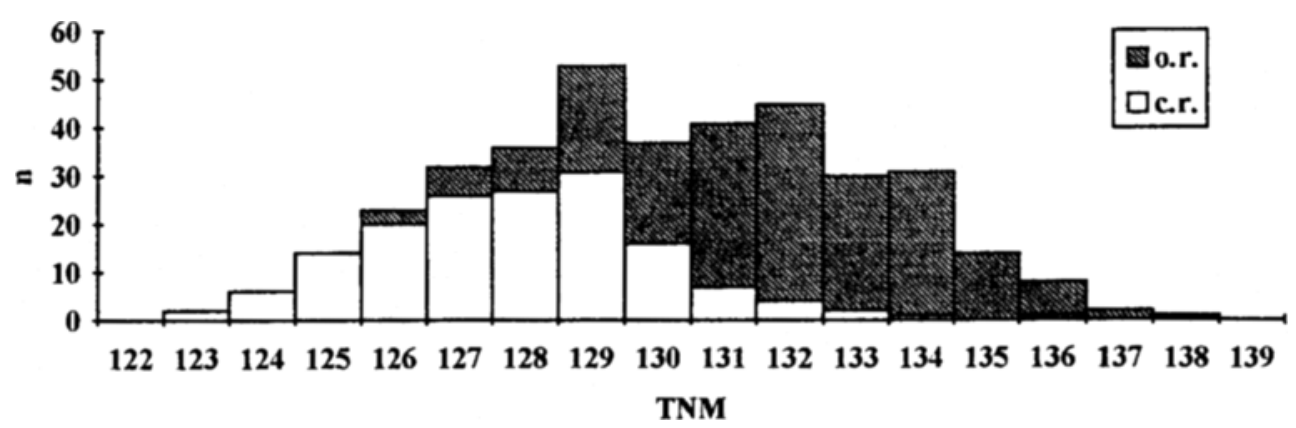

Fig. 5. Frequency distribution of total numbers of myomeres of A. balearicum caught in Mediterranean and coastal regions (c.r. - values of Grassi, 1913; Strehlow, 1992; Blache, 1977; Castle, 1966) and oceanic regions of the NE-Atlantic (o. r. - values of Blache, 1977; Lea, 1913) 
The occurrence of larvae and adults of $A$. balearicum all over the Atlantic and in the Mediterranean is supplemented by a report of adult specimens in the Red Sea and in the North-West of the Indian Ocean (Blache \& Bauchot, 1972). Mochioka et al. (1991) studied 57 larvae of Ariosoma (Type II) with a TL between 33 and $210 \mathrm{~mm}$ which very well agreed with $A$. balearicum. In agreement with an irregular worldwide occurrence is also the existence of additional spawning areas which very likely are indicated by the catch of very small larvae in the West-Atlantic (Smith, 1989) and in the NW-Pacific south of Okinawa (Mochioka et al., 1991). However, the species structure of Ariosoma in the Indowest Pacific appears to be complex but unresolved (Castle, pers. comm.), and despite the similarity of myomere numbers it would be premature to synonymise the Indo-west Pacific Ariosoma with $A$. balearicum.

On the basis of our material, the suggested northern boundary of distribution in the East Atlantic can be moved from $32^{\circ} \mathrm{N}$ to $48^{\circ} \mathrm{N}$. To overcome the unequivocal systematic status of the larvae of $A$. balearicum with different TNM, molecular biological investigations should be applied.

\section{Ariosoma selenops}

During the expedition of R. V. "Prof. Siedlecki" 1984 in the Iberian Basin an Ariosoma larva of unusual size and high myomere count was caught ( $\left.48^{\circ} 52,8^{\prime} \mathrm{N}, 26^{\circ} 59,8^{\prime} \mathrm{W}\right)$. The larva seems to be identical to the larva of A. selenops as described by Smith (1989) from the western Atlantic. After examination it was retained in the collection of the "Museum für Naturkunde", Berlin.

The total length of the larva was $467 \mathrm{~mm}_{\text {; }}$ after being preserved in seawater formalin (4\%) for five years it shrank by $7.9 \%$ to $430 \mathrm{~mm}$. The maximum body depth is directly behind the head; but the last third of the body is much narrower. The small head is characterized by large round eyes (diameter of circular eye $1.7 \mathrm{~mm}$ ); the mouth cleft $(4.8 \mathrm{~mm})$ is in line with the centre of the eye; 21 teeth are in the upper jaw - uniform in shape and size (the lower jaw was somewhat damaged); an oval nasal capsule with two round nostrils is level with the upper half of eyes. The dorsal, caudal and short anal fin combine in a continuous fin and there are two hypurals. The gut is straight without any swellings or arches. The length of the filamentous exterilium was $18.4 \mathrm{~mm}$ $(4.2 \%$ of $\mathrm{TL})$. In the completely transparent larva some fine irregular pigment in the anterior part of the gut and liver are obvious. Besides lateral pigment on the posterior half of the body, minute melanophores are present on the myosepta below the chorda and form short diagonal lines directed caudally. Details of morphometric and meristic characters in comparison with other known examples of the species are given in Table 9.

Larvae of $A$. selenops are only known from the western and central North Atlantic (Smith, 1989: 29 specimens of 24-344 mm SL; Keller, 1976: 5 specimens of 349-402 mm TL). Van Utrecht (1988) described a giant example of "Leptocephalus pseudomicrocephalus" in the Iberian Basin as a new, hitherto undescribed type of congrid larva. A comparison of distinct characters shows that both examples from the eastern Atlantic corresponded with the larvae of $A$. selenops known from the western Atlantic. Mochioka et al. (1982) recorded similar larvae, possibly of more than one species, in the western part of the Pacific Ocean. His Ariosoma Typ A4 and A5 larvae corresponded in their high count of myomeres, but larvae of both described species have an arch in the gut and 
Table 9. Comparison of morphometric and meristic characters of Ariosoma selenops larvae in the North Atlantic and of similar eel larvae from the Western Pacific

\begin{tabular}{|c|c|c|c|c|c|}
\hline Parameter & $\begin{array}{l}\text { Strehlow } \\
\text { (1992) }\end{array}$ & $\begin{array}{l}\text { Smith } \\
\text { (1989) }\end{array}$ & $\begin{array}{l}\text { v. Utrecht } \\
(1988)^{*}\end{array}$ & $\begin{array}{l}\text { Mochioka et } \\
\text { al. }(1982)^{\cdots}\end{array}$ & $\begin{array}{l}\text { Mochioka et } \\
\text { al. }(1982)^{*} \cdots\end{array}$ \\
\hline $\mathrm{N}$ & 1 & 29 & 1 & 6 & 4 \\
\hline \multirow[t]{2}{*}{$\mathrm{TL}(\mathrm{mm})$} & 467 & $24-344$ & 373 & $41.8-398$ & $41.5-187$ \\
\hline & \multicolumn{5}{|c|}{ Proportions $(\%$ of TL) } \\
\hline PreAL ${ }^{+}$ & 98.6 & $96-98$ & - & 96.9 & 95.7 \\
\hline PreDL & 98.1 & - & - & 96.0 & 95.2 \\
\hline LBO & 51.2 & - & - & - & - \\
\hline LH & 2.1 & $4-10$ & 2.1 & 4.3 & 3.3 \\
\hline \multirow[t]{2}{*}{$\mathrm{D}$} & 8.3 & $9-14$ & 9.3 & 8.9 & 9.9 \\
\hline & \multicolumn{5}{|c|}{ Meristic values } \\
\hline TNM & 171 & $169-174$ & 172 & $160-173$ & $171-177$ \\
\hline MP & 30 & - & - & $20-23$ & $8-14$ \\
\hline MO & 88 & $96-103$ & 91 & $78-91$ & $101-104$ \\
\hline MA & 167 & $160-169$ & 170 & $151-161$ & $159-166$ \\
\hline MD & 165 & - & 169 & $149-157$ & $149-164$ \\
\hline FC & 9 & - & - & 9 & 8 \\
\hline \multicolumn{6}{|c|}{$\begin{array}{l}\text { * described as Leptocephalus pseudomicrocephalus } \\
\text { * described as Ariosoma Type A4 } \\
\text { - described as Ariosoma Type A5 } \\
{ }^{+} \text {measured to the point where the gut becomes free of body }\end{array}$} \\
\hline
\end{tabular}

several dorsal and anal pigments, the outer intestine in Ariosoma Typ A5 is longer $(77.8 \%$ of TL - Table 9).

The enormous size of the specimens from the Iberian Basin and the presence of smaller larvae of the species in the western part of Atlantic could be indicative of an extended larval phase and a spawning area in the western Atlantic. Adults of A. selenops, known only from the western North Atlantic, have total lengths of about $500 \mathrm{~mm}$. The larvae reach much more than half the TL of the largest known adults $(>90 \%)$, giving this species one of the largest larva-to-adult size ratios of any eel. The larva of $A$. selenops studied here seems to belong to the longest of all known eel larvae. Only four leptocephali of Anguilliformes and Notacanthiformes with greater TL have been described (Bertin, 1954; Castle, 1959, 1967: L. giganteus of 565, 900 and $1800 \mathrm{~mm}$; Castle, 1967: Ascomana eximia of $700 \mathrm{~mm}$ ).

\section{Unidentified Ariosoma species}

During the expedition of R.V. "Prof. Siedlecki" in 1985 two larvae were captured which resembled $A$. balearicum in shape and pigmentation. However, they had higher numbers of myomeres (151 and 152) than $A$. balearicum (123-138). From the WestAtlantic only one species (A. anale) is known that exhibits a high number of myomeres (Smith, 1989: TNM $=147-155 ; n=19)$. Blache $(1968,1977)$ likewise described a number of Ariosoma larvae from the Central Atlantic and from the Gulf of Guinea with a TNM 
between 141 and $154\left(\mathrm{TL}=5.4-275 \mathrm{~mm} ; \mathrm{MO}=60-99 ; \mathrm{MA}=134-142_{i} \mathrm{n}=56\right)$. The larvae were differently described, like Cynoponticus ferox, Parabathymyrus sp. and Ariosoma melissi. Smith (1989) associated all specimens studied by Blache $(1968,1977)$ with Ariosoma anale. However, the two individuals collected during our expedition could not be $A$. anale, because they exhibit neither the three lateral rows of pigment series nor the exterilium, typical of this size and developmental stage. The few known adult specimens of A. mellissi (Blache \& Bauchot, 1976; Smith, 1981) showed a number of vertebrae between 140 and 142 which is distinctly below the TNM of two larvae under investigation, making their identity questionable. Confirmed larvae of $A$. mellissi are not known.

In addition to the two sampled larvae, seven further specimens, very similar to A. balearicum, stored in the "Museum für Naturkunde" in Berlin, were studied. They were captured by the "E. Haeckel"-Expedition 1968 in the Atlantic Ocean. These leptocephali were $130-255 \mathrm{~mm}$ and had 123 to 140 preanal myomeres. The exact TNM could not be counted because of the poor condition of the preserved specimens, but they were distinctly above 138 .

Table 10. Comparison of morphometric and meristic characters of leptocephali of Ariosoma species in the North Atlantic

\begin{tabular}{|c|c|c|c|c|}
\hline Parameter & $\begin{array}{l}\text { Strehlow } \\
\text { (1992) }\end{array}$ & $\begin{array}{c}\text { Fortuna \& } \\
\text { Olivar (1986) }\end{array}$ & $\begin{array}{l}\text { Smith } \\
\text { (1989) }\end{array}$ & $\begin{array}{c}\text { Mochioka et al. } \\
(1991)^{\circ}\end{array}$ \\
\hline$N$ & 2 & 1 & 5 & 783 \\
\hline \multirow[t]{2}{*}{$\mathrm{TL}(\mathrm{mm})$} & $117-123$ & 79 & $20-230$ & $11.9-282.2$ \\
\hline & \multicolumn{4}{|c|}{ Proportions (\% of TL) } \\
\hline preAL & 95.5-95.9 & - & $94-95$ & - \\
\hline $\mathrm{LH}$ & $3.2-7.1$ & - & $5-9$ & - \\
\hline \multirow[t]{2}{*}{$\mathrm{D}$} & $6.8-6.9$ & - & $9-13$ & - \\
\hline & \multicolumn{4}{|c|}{ Meristic values } \\
\hline TNM & $151-152$ & 148 & $148-149$ & $136-151$ \\
\hline $\mathrm{MO}$ & $70-71$ & 82 & $76-79$ & $71-80$ \\
\hline MA & $134-137$ & 138 & 133 & $131-142$ \\
\hline
\end{tabular}

Good agreement in all essential features of the two larvae described was obtained in the description of the following material of Ariosoma larvae: Fortuno \& Olivar (1986) from the Southeast Atlantic, Smith (1989) from different areas of the West-Atlantic, Mochioka et al. (1982) from the North and Central Pacific (Ariosoma Type III, without exterilium Table 10). Castle (1964) as well described very similar larvae of A. mauritianum from the South Pacific showing no exterilium. These larvae exhibited a frequency distribution of 134 to 153 TNM showing probably two maxima at 142 and 151 . The larvae with the higher number of myomeres therefore are similar to the studied leptocephali of the genus Ariosoma. Nothing is known about the distribution, ecology or relationship to other species of Ariosoma of these unidentified species. 


\section{Other Congridae}

Not all congrid larvae shown in Table 11 could be identified definitely to species level. The identification of the Gnathophis larvae has been very difficult up to now. The eight larvae captured in the Iberian Basin exhibited good agreement with Gnathophis mystax except that there was no lateral pigment and only very sparse intestinal pigmentation. They also had a distinctly higher number of myomeres $(\varnothing \mathrm{TNM}=144.25$; s.d. $=$ 1.49) than G. mystax leptocephali (this paper: $\varnothing \mathrm{TNM}=138.73 ; \mathrm{n}=15$; s.d. $=0.96$; Blache, 1977: $\varnothing \mathrm{TNM}=135.50 ; \mathrm{n}=12 ; \mathrm{s} . \mathrm{d} .=3.09$ ). Taxonomically they therefore could belong to $G$. codoniphorus. This is a second species of the genus known from this area. But only one juvenile and two post-larvae are reported for this species which agreed in numbers of myomeres and vertebrae of 144 (Maul, 1972). Gnathophis larvae with 132-147 TNM from the Central Atlantic were reported by Lea (1913).

Leptocephali of Paraconger differ from other congrid leptocephali in having a shorter dorsal fin, blade shaped posterior teeth and no suborbital pigment. Only one species is known in the East-Atlantic which was identified from metamorphic specimens by

Table 11. Leptocephali of other congrid species among the examined material

\begin{tabular}{|c|c|c|c|c|c|}
\hline Species & $\begin{array}{l}\text { Exp.-Nr. } \\
\text { (Table 1) }\end{array}$ & $\mathrm{n}$ & Catching positions & $\mathrm{TL}(\mathrm{mm})$ & $\begin{array}{l}\varnothing \mathrm{TL} \\
(\mathrm{mm})\end{array}$ \\
\hline Acromycter perturbator & 1 & 1 & $?$ & 163 & 163.0 \\
\hline Gnathophis trios & 1 & 6 & $57.2-63.2^{\circ} \mathrm{W} ; 31.4-33.4^{\circ} \mathrm{W}$ & $55-94$ & 80.6 \\
\hline G. bracheotopos & 1 & 3 & $64.1^{\circ} \mathrm{W} ; 31.4^{\circ} \mathrm{N}$ & $42-61$ & 49.3 \\
\hline G. bathytopos & 1 & 9 & $64.2^{\circ} \mathrm{W}_{i} 31.4^{\circ} \mathrm{N}$ & $35-62$ & 55.4 \\
\hline Gnathophis sp. & 1 & 109 & $46.0-66.1^{\circ} \mathrm{W} ; 10.4-37.5^{\circ} \mathrm{N}$ & $29-128$ & 70.2 \\
\hline Gnathophis sp. & 4 & 49 & $9.6-67.1^{\circ} \mathrm{W} ; 18.1-37.4^{\circ} \mathrm{N}$ & $17-135$ & 71.6 \\
\hline Gnathophis sp. & 5 & 34 & $9.4-22.3^{\circ} \mathrm{W}_{;} 36.2-39.2^{\circ} \mathrm{N}$ & $22-134$ & 66.0 \\
\hline Gnathophis sp. & 7 & 33 & $7.1-9.3^{\circ} \mathrm{W} ; 36.2-38.1^{\circ} \mathrm{N}$ & $42-124$ & 74.8 \\
\hline G. mystax & 8 & 15 & $15.6-29.5^{\circ} \mathrm{W} ; 37.0-51.6^{\circ} \mathrm{N}$ & $104-150$ & 122.6 \\
\hline Gnathophis sp." & 8 & 8 & $12.0-27.0^{\circ} \mathrm{W} ; 37.1-45.6^{\circ} \mathrm{N}$ & $95-137$ & 115.0 \\
\hline Gnathophis sp. & 18 & 5 & $59.2-62.0^{\circ} \mathrm{W} ; 24.5-32.0^{\circ} \mathrm{N}$ & $65-72$ & 69.8 \\
\hline Hildebrandia sp. & 1 & 22 & $31.4-61.6^{\circ} \mathrm{W}_{i} 25.3-63.2^{\circ} \mathrm{N}$ & $26-123$ & 59.6 \\
\hline Hildebrandia sp. & 4 & 4 & $66.0^{\circ} \mathrm{W} ; 25.5^{\circ} \mathrm{N}$ & $47-134$ & 92.2 \\
\hline Paraconger notialis & 9 & 6 & $7.0-7.4^{\circ} \mathrm{W}_{i} 35.3-35.4^{\circ} \mathrm{N}$ & $26-59$ & 45.5 \\
\hline Pseudophichthys sp. & 1 & 3 & $10.6^{\circ} \mathrm{W} ; 45.5^{\circ} \mathrm{N}$ & $89-107$ & 95.3 \\
\hline Rhechias sp. & 1 & 14 & $57.0-67.4^{\circ} \mathrm{W} ; 21.0-29.5^{\circ} \mathrm{N}$ & $103-160$ & 135.9 \\
\hline Rhechias sp. & 4 & 1 & $67.1^{\circ} \mathrm{W} ; 24.5^{\circ} \mathrm{N}$ & 64 & 64.0 \\
\hline Uroconger syringinus & 1 & 3 & $57.2-61.2^{\circ} \mathrm{W}_{i} 26.5-33.4^{\circ} \mathrm{N}$ & $71-118$ & 89.0 \\
\hline Xenomystax congroides & 1 & 25 & $55.3-64.0^{\circ} \mathrm{W} ; 19.5-33.4^{\circ} \mathrm{N}$ & $91-212$ & 152.8 \\
\hline$X$. congroides & 4 & 2 & $66.0-66.1^{\circ} \mathrm{W} ; 25.5-26.4^{\circ} \mathrm{N}$ & $91-145$ & 118.0 \\
\hline$X$. congroides & 18 & 2 & $62.0-63.0^{\circ} \mathrm{W} ; 24.5-26.0^{\circ} \mathrm{N}$ & $154-175$ & 164.5 \\
\hline
\end{tabular}


Blache (1977). The East-Atlantic larvae of Paraconger notialis all have higher numbers of myomeres (this paper: TNM $=133-136 ; n=7$; Blache, 1977: TNM $=132-144 ; \mathrm{n}=122$ ) than the species known from the West-Atlantic (Smith, 1989: TNM $=119-131 ; n=133$ ). The collection of Paraconger notialis in 1984 in the area of Gibraltar shows that this species occurs also in the East-Atlantic.

All 29 larvae of Xenomystax congroides were caught in the Sargasso Sea during spring. The number of myomeres varies between 203 and $212(n=12)$ and supports the hypothesis of Smith (1989) of four distinct Atlantic populations which can be identified by number of myomeres or vertebrae. Leptocephali of the Caribbean population and from the area near Bermuda have the highest numbers of myomeres (Smith, 1989: TNM = 200-212; Keller, 1976: TNM = 221).

Acknowledgements. We would like to thank P. H. J. Castle for critical discussion, and C. Berger for valuable hints concerning the English text.

\section{LITERATURE CITED}

Antunes, C., 1994. Estudo da migraçao e metamorfose de Anguilla anguilla L. por análise dos incrementos dos sagittae, em leptocéfalos e enguias de vidro. Diss., Univ. Porto, 294 pp.

Antunes, C. \& Tesch, F.-W., 1997. A critical consideration of the metamorphosis zone when identifying daily rings in the otoliths of European eel, Anguilla anguilla (L.). - Ecol. Freshwat. Fish 6 , 102-107.

Bertin, L., 1954. Les larves leptocephaliennes géantes et le problème du "serpent de mer". - Nature, Paris 82, 312-313.

Blache, J., 1968. Contribution à la connaissance des poissons anguilliformes de la côte occidentale d' Afrique, Septième note: La famille des Muraenesocidae. - Bull. Inst. fr. Afr. noire (Sér. A) 30. $690-736$.

Blache, J., 1977. Leptocephales des poissons anguilliformes dans la zone sud du Golfe de Guinée. Faune trop. 20, 1-381.

Blache, J. \& Bauchot, M.-L., 1972. Contribution à la connaissance des poissons anguilliformes de la còte occidentale d' Afrique, Troisième note: Les genres Verma, Apterichthus, Ichthyapus, Hemerorhinus, Caecula, Dalophis avec la description de deux genres nouveaux (Fam. des Ophichthidae). - Bull. Inst. fr. Afr. noire (Sér. A) 34, 692-773.

Blache, J. \& Bauchot, M.-L., 1976. Contribution à la connaissance des poissons anguilliformes de la côte occidentale d' Afrique, Note 16: Les familles des Congridae et Colocongridae. - Bull. Inst. fr. Afr. noire (Sér. A) 38, 369-444.

Böhlke, J. E. \& Chaplin, C. C. G., 1968. Fishes of the Bahamas and the adjacent tropical waters. Livingston Press, Wynnewood, 771 pp.

Castle, P. H. J., 1959. A large leptocephalid (Teleostei, Apodes) from off South Westland, New Zealand. - Trans. R. Soc. N. Z. 87, 179-184.

Castle, P. H. J., 1964. Congrid leptocephali in Australian waters with descriptions of Conger wilsoni (Bl. and Sch.) and C. verreauxi Kaup. - Zool. Publ. Vict. Univ. Wellington 37, 1-45.

Castle, P. H. J., 1966. Die ichthyologische Ausbeute der ersten Westafrika-Fahrt des fischereitechnischen Forschungsschiffes "Walther Herwig“. 3. The eel larvae (leptocephalj). - Arch. FischWiss. 17, 19-35.

Castle, P. H. J., 1967. Two remarkable eel-larvae from off Southern Africa. - Spec. Publ. Dep. Ichthyol. Rhodes Univ. 1, 1-121.

Castle, P. H. J., 1970. Ergebnisse der Forschungsreisen des FFS „Walther Herwig“ nach Südamerika. 9. The leptocephali.- Arch. FischWiss. 21, 1-21.

D'Ancona, U., 1931. Uova, larve e stadi giovanili di Teleostei, Ordine: Apodes. - Fauna Flora Golfo Napoli 38, 94-156.

Fortuno, J. M. \& Olivar, M. P., 1986. Larvas de Anguilliformes Capturadas en el Atlantico Sudoriental. - Miscnea zool. 10, 223-231. 
Grassi, B., 1913. Contributo alla conoscenza delle uova e delle larve dei Murenoidi. - Memorie R. Com. talassogr. ital. 45, 1-32.

Keller, A., 1976. Systematics, vertical distribution and the life history of anguilliform leptocephali in the Bermuda Ocean Acre. Diss., Univ. of Rhode Island, $256 \mathrm{pp}$.

Lea, E., 1913. Muraenoid larvae from the "Michael Sars" North Atlantic Deep-Sea Expedition, 1910. - Rep. scient. Results "Michael Sars" N. Atlant. deep-Sea Exped. 3, 1-59.

Maul, G. E., 1972. A new species of eel of the genus Gnathophis (Apodes, Congridae) from the Meteor Seamount. - Bocagiana 8 (VI), 1-7.

McCleave, J. D. \& Miller, M. J., 1994. Spawning of Conger oceanicus and Conger triporiceps (Congridae) in the Sargasso Sea and subsequent distribution of leptocephali. - Envir. Biol. Fish. 39, 339-355.

Mochioka, N., Kakuda, S. \& Tabeta, O., 1982. Congrid leptocephali in the western North and Middle Pacific, I. Exterilium Ariosoma Type Larvae. - J. Fac. biol. Sci. Hiroshima Univ. 21, 35-66.

Mochioka, N., Tabeta, O., Kakuda, S. \& Tsukahara, H., 1991. Congrid leptocephali in the western North and Middle Pacific. II. Non-Exterilium Ariosoma Type Larvae. - Bull. mar. Sci. 48, 606-622.

Schmidt, J., 1912. Contributions to the biology of some North Atlantic species of eels. - Vidensk. Meddr naturh. Foren 64, 39-51.

Schmidt, J., 1913. First report on eel investigations 1913. - Rapp. P.-v. Reun. Cons. int. Explor. Mer $18(2), 1-29$.

Schmidt, J., 1931. Eels and conger eels of the North Atlanic. - Nature, Lond. 128, 602-604.

Smith, D. G., 1971. Osteology and relationships of the congrid eels of the western North Atlantic (Pisces, Anguilliformes). Diss., Univ. of Miami, 163 pp.

Smith, D. G., 1981. Congridae, Muraenesocidae. In: F. A. O. species identification sheets for fishery purposes (Fishing areas 34,47/Eastern Central Atlantic). Ed. by W. Fischer, G. Bianchi \& W. B. Scott. Department of Fisheries and Oceans, Ottawa, 2.

Smith, D. G., 1989. Family Congridae, Leptocephali. In : Fishes in the Western North Atlantic. Ed. by E. B. Böhlke. Sears Foundation for Marine Research, New Haven, 9, 2, 1-1055.

Strehlow, B., 1992. Untersuchungen an Leptocephali und adulten Exemplaren der Ordnung Anguilliformes aus dem Iberischen Becken und dem Seegebiet vor Nordwestafrika. Diss., Univ. Rostock, $208 \mathrm{pp}$.

Tesch, F.-W., 1980. Occurrence of eel Anguilla anguilla larvae west of the European continental shelf, 1971-1977. - Envir. Biol. Fish. 5, 185-190.

Tesch, F.-W., 1982. The Sargasso Sea eel expedition 1979. - Helgoländer Meeresunters. 35, $263-277$.

Tesch, F.-W., 1983. Der Aal. Parey, Hamburg, 340 pp.

Tesch, F.-W. \& Niermann, U., 1992. Stock density of eel larvae (Anguilla anguilla L.) on the European continental slope, based on collections made between 1985 and 1989. - Ir. Fish. Invest. (Ser. A) $36,110-113$

Tesch, F.-W. \& Wegner, G., 1990. The distribution of small larvae of Anguilla sp., related to hydrographic conditions 1981 between Bermuda and Puerto Rico. - Int. Revue ges. Hydrobiol. 75, $845-858$.

Tesch, F.-W., Niermann, U. \& Plaga, A., 1986. Differences in development stage and stock density of larval Anguilla anguilla off the west coast of Europe. - Vie Milieu 36, 255-260.

Utrecht, W. L. van, 1988. A new eel larva, Leptocephalus pseudomicrocephalus, belonging to the subfamily Bathymyrinae (Anguilliformes, Congridae). - Bull. zool. Mus. Univ. Amsterdam 11, 149-152. 